American Journal of Applied Sciences 6 (8): 1613-1617, 2009

ISSN 1546-9239

(C) 2009 Science Publications

\title{
Antimicrobial Activity of Some Medicinal Plants from Malaysia
}

\author{
Koshy Philip, Sri Nurestri Abd Malek, Wirakarnain Sani, Sim Kae Shin, Saravana Kumar, \\ Hong Sok Lai, Lee Guan Serm and Syarifah N.S.A. Rahman \\ Institute of Biological Sciences, Faculty of Science, University of Malaya, \\ 50603, Kuala Lumpur, Malaysia
}

\begin{abstract}
Problem statement: About 32 extracts from eight selected medicinal plants, namely Pereskia bleo, Pereskia grandifolia, Curcuma aeruginosa Roxb., Curcuma zedoria, Curcuma mangga, Curcuma inodora aff. Blatter, Zingiber officinale var. officinale (jahe gajah) and Zingiber officinale var. rubrum (jahe emprit) used by Malaysia traditional health care systems were screened for their antimicrobial activity against both Gram-positive bacteria and Gram-negative bacteria using agar disc diffusion assay. Approach: The efficacy of the extracts was compared to the commercially prepared antibiotic diffusion discs. Results: No inhibition was observed with the water fractions. Conclusion/Recommendations: None of the plants tested showed inhibition against Escherichia coli. Curcuma mangga showed some remarked inhibition against the bacteria used in this study.
\end{abstract}

Key words: Antimicrobial activity, agar disc diffusion assay, Malaysia medicinal plants

\section{INTRODUCTION}

Natural products perform various functions, and many of them have interesting and useful biological activities $^{[3]}$. There are more than 35,000 plant species being used in various human cultures around the world for medicinal purpose. In Peninsular Malaysia, 1,200 species of higher plants and 2,000 species in Sabah and Sarawak are reported to have medicinal value and have been used for generations in various traditional health care systems ${ }^{[5]}$. Researchers are increasingly turning their attention to natural products looking for new leads to develop better drugs against cancer, as well as viral and microbial infections ${ }^{[3,4,15]}$

This study reports a screening programme of 32 methanolic extracts and from eight medicinal plants in Malaysia for their antimicrobial properties against two Gram-positive bacteria and two Gram-negative bacteria. These plants included two families namely Cactaceae (Pereskia bleo and Pereskia grandifolia) and Zingiberaceae (Curcuma aeruginosa Roxb., Curcuma zedoria, Curcuma mangga, Curcuma inodora aff. Blatter, Zingiber officinale var. officinale and Zingiber officinale var. rubrum). There were no previous reports of antimicrobial study on Pereskia bleo, Pereskia grandifolia, Curcuma mangga and Curcuma inodora aff. Blatter.
There were numerous antimicrobial studies conducted on both essential oils and extracts of common ginger (Zingiber officinale var. officinale). However, there is no report on the antimicrobial activity of the variants of Zingiber officinale such as jahe emprit (Zingiber officinale var. rubrum) and jahe gajah (Zingiber officinale var. officinale). Sofia et al. ${ }^{[14]}$ reported that the ginger extract showed insignificant antibacterial activity against Escherichia coli, Staphylococcus aureus and Bacillus cereus. In 2005, Lopez et $a l .{ }^{[7]}$. reported that essential oil of ginger showed weakest inhibition against selected bacteria and fungi whilst Rath et al. ${ }^{13]}$. reported that essential oil of ginger did not show any inhibition on the tested pathogens in their study.

Extracts of Curcuma aeruginosa obtained from supercritical fluid extraction have shown negligible inhibition activity against Gram negative bacteria Escherichia coli and yeast Malassezia furfur ${ }^{[8,9]}$. from Vietnam, however, isolated sesquiterpene constituents from the petroleum ether extract of Curcuma aeruginosa and found that these compounds have a broad spectrum of antimicrobial activity. There are a number of papers reported the antimicrobial activity of the essential oil of Curcuma zedoaria against Gram positive and negative pathogenic microorganism ${ }^{[2,6,12,16]}$ reported that petroleum ether, hexane, chloroform, acetone and ethanolic extracts of Curcuma zedoaria

Corresponding author: Koshy Philip, Institute of Biological Sciences, Faculty of Science, University of Malaya, 0603 Kuala Lumpur, Malaysia 
exhibited antibacterial and antifungal activity whilst Phan et al ${ }^{[8]}$ isolated sesquiterpene constituents from the petroleum ether extract of Curcuma zedoaria which showed active inhibition against Candida albicans.

\section{MATERIALS AND METHODS}

Plant material: Eight traditional medicinal plants used in this study were Pereskia bleo, Pereskia grandifolia, Curcuma aeruginosa Roxb., Curcuma zedoria, Curcuma mangga, Curcuma inodora aff. Blatter, Zingiber officinale var. officinale and Zingiber officinale var. rubrum. These medicinal plants were chosen based on their traditional medicinal use and reported biological activities. The fresh leaves of Pereskia bleo and Pereskia grandifolia were collected from Petaling Jaya, Selangor, Malaysia in May 2007. The rhizomes of Curcuma aeruginosa, Curcuma mangga, Zingiber officinale var. officinale and Zingiber officinale var. rubrum were obtained from Jogjakarta, Indonesia in 2006. Whereas both rhizomes of Curcuma zedoaria and Curcuma inodora were obtained from MARDI Kluang, Johor, Malaysia in January 2007. They were identified by Professor Dr. Halijah Ibrahim of Institute of Biological Sciences, Faculty of Science, University of Malaya, Malaysia and voucher specimens were deposited at the herbarium of the Institute of Biological Sciences, Faculty of Science, University of Malaya, Kuala Lumpur, Malaysia.

Extraction of plant material: The fresh samples were washed, dried and ground to fine powders using a blender. The dried, ground samples were then soaked in methanol $(1.5 \mathrm{~L})$ for 3 days at room temperature. The solvent-containing extracts were then decanted and filtered. The extractions of the ground samples were further repeated $(2 \mathrm{x})$ with methanol $(1.5 \mathrm{~L}$ each time). The filtrate from each extraction was combined and the excess solvent was evaporated under reduced pressure using a rotary evaporator to give crude methanol extracts. The methanol extracts were further extracted with hexane to give hexane-soluble fractions and hexane insoluble residues. The hexane-insoluble residues were further partitioned between ethyl acetatewater (ratio 1:1) to give ethyl acetate-soluble fractions. The water layers were freeze-dried to give water fractions. All the extracts and fractions were stored at $4^{\circ} \mathrm{C}$ for determination of antibacterial activity.

Test microorganisms and microbial culture: Four bacterial strains were used in this study: Gram negative bacteria; Escherichia coli, Pseudomonas aeruginosa, Gram positive bacteria; Staphylococcus aureus, Bacillus subtilis. The test microorganisms were obtained from the Microbiology Laboratory, Microbiology Division, Institute of Biological Sciences, Faculty of Science, University of Malaya, Malaysia. Bacterial strains were cultivated at $37^{\circ} \mathrm{C}$ and maintained on nutrient agar (Difco, USA) slant at $4^{\circ} \mathrm{C}$.

Antimicrobial activity assay: Antimicrobial activity was determined against four bacterial pathogens by the agar disc diffusion assay (NCCLS (National Committee for Clinical Laboratory Standards), 2005). The crude methanol and fractionated extracts were dissolved in Dimethyl Sulfoxide (DMSO) with the exception of the water fraction and then antimicrobial effect of crude methanol and fractionated extracts were tested using two different concentrations. Petri dishes (measuring $90 \mathrm{~mm}$ each side) containing $20 \mathrm{~mL}$ of mueller hinton agar (OXOID). At the same time, $6 \mathrm{~mm}$ diameter sterile Whatman Antibiotic disc were placed on the surface of the inoculated agar plates, and then appropriate concentration of the extracts in DMSO and water were applied onto the discs, 50 and $500 \mathrm{mg}$ final concentrations were obtained for each discs. The plates were incubated at $37^{\circ} \mathrm{C}$ for $16-18 \mathrm{~h}$. The antibacterial activity was evaluated by measuring the zone of growth inhibition surrounding the discs. Standard discs of the antibiotic gentamycin $(10 \mu \mathrm{g})$ and ampicilin $(10 \mu \mathrm{g})$ served as the positive antibacterial controls. Negative controls were done using paper discs loaded with $20 \mu \mathrm{L}$ of DMSO and water. After that, the diameter of inhibition zone was measured in millimeters by Vernier Calipers. All tests were repeated three times to minimize test error. An inhibition zone of $14 \mathrm{~mm}$ or greater (including diameter of the disc) was considered as high antibacterial activity ${ }^{[11]}$.

\section{RESULTS AND DISCUSSION}

This study reports the antimicrobial activity of 32 extracts from eight selected medicinal plants in Malaysia against two Gram positive bacteria and two Gram-negative bacteria, including Escherichia coli, Pseudomonas aeruginosa, Staphylococcus aureus and Bacillus subtilis. The results of the antimicrobial activity of the investigated extracts are shown in Table 1 . None of the extracts showed activity against Escherichia coli. All the water fractions of the eight selected plants showed no inhibition against all the bacteria tested in this study. Generally, among the investigated extracts the ethyl acetate fractions exhibited the highest antibacterial effect followed by the methanol extracts. 
Am. J. Applied Sci., 6 (8): 1613-1617, 2009

Table 1: Results of the antimicrobial tests of the investigated plants in agar diffusion assay

\begin{tabular}{|c|c|c|c|c|c|c|}
\hline \multirow[b]{2}{*}{ Plant species } & \multirow[b]{2}{*}{ Extracts /fractions } & \multirow[b]{2}{*}{ Concentration $\left(\mathrm{mg} \mathrm{mL}^{-1}\right)$} & \multicolumn{4}{|c|}{ Inhibition zone $(\mathrm{mm})^{\mathrm{a}}$ against } \\
\hline & & & E. $c$ & P. $a$ & S. $a$ & B. $s$ \\
\hline \multirow[t]{8}{*}{ Pereskia bleo } & Methanol & 50 & - & 8.3 & - & - \\
\hline & & 500 & - & 9.8 & - & - \\
\hline & Hexane & 50 & - & - & - & - \\
\hline & & 500 & - & 9.5 & - & 8.2 \\
\hline & Ethyl acetate & 50 & - & 7.3 & - & - \\
\hline & & 500 & - & 8.5 & - & 7.8 \\
\hline & Water & 50 & - & - & - & - \\
\hline & & 500 & - & - & - & - \\
\hline \multirow{8}{*}{ Pereskia grandifolia } & Methanol & 50 & - & - & - & - \\
\hline & & 500 & - & - & - & - \\
\hline & Hexane & 50 & - & - & - & - \\
\hline & & 500 & - & - & - & - \\
\hline & Ethyl acetate & 50 & - & - & - & - \\
\hline & & 500 & - & 8.0 & 9.2 & 8.5 \\
\hline & Water & 50 & - & - & - & - \\
\hline & & 500 & - & - & - & - \\
\hline \multirow{8}{*}{ Curcuma aeruginosa Roxb } & Methanol & 50 & - & - & - & - \\
\hline & & 500 & - & 7.0 & - & - \\
\hline & Hexane & 50 & - & 7.2 & - & - \\
\hline & & 500 & - & 7.5 & 7.5 & - \\
\hline & Ethyl acetate & 50 & - & - & - & 7.0 \\
\hline & & 500 & - & 7.8 & 6.7 & 9.0 \\
\hline & Water & 50 & - & - & - & - \\
\hline & & 500 & - & - & - & - \\
\hline \multirow{8}{*}{ Curcuma zedoaria } & Methanol & 50 & - & - & - & - \\
\hline & & 500 & - & 7.0 & - & - \\
\hline & Hexane & 50 & - & - & 7.5 & - \\
\hline & & 500 & - & 7.7 & 8.5 & 8.5 \\
\hline & Ethyl acetate & 50 & - & - & - & - \\
\hline & & 500 & - & - & - & 8.2 \\
\hline & Water & 50 & - & - & - & - \\
\hline & & 500 & - & - & - & - \\
\hline \multirow{8}{*}{ Curcuma mangga } & Methanol & 50 & - & 7.2 & 7.5 & 9.3 \\
\hline & & 500 & - & 13.0 & 10.5 & 19.3 \\
\hline & Hexane & 50 & - & 8.5 & 7.7 & 11.3 \\
\hline & & 500 & - & 15.0 & 9.5 & 13.5 \\
\hline & Ethyl acetate & 50 & - & - & 7.0 & 8.7 \\
\hline & & 500 & - & 11.5 & 9.0 & 13.7 \\
\hline & Water & 50 & - & - & - & - \\
\hline & & 500 & - & - & - & - \\
\hline Curcuma inodora aff. & Methanol & 50 & - & - & - & 7.3 \\
\hline \multirow{7}{*}{ Blatter } & & 500 & - & 7.8 & 8.3 & 8.0 \\
\hline & Hexane & 50 & - & - & - & - \\
\hline & & 500 & - & 7.7 & 6.7 & - \\
\hline & Ethyl acetate & 50 & - & - & - & 7.5 \\
\hline & & 500 & - & 7.8 & 10.0 & 9.0 \\
\hline & Water & 50 & - & - & - & - \\
\hline & & 500 & - & - & - & - \\
\hline Zingiber officinale & Methanol & 50 & - & - & - & - \\
\hline \multirow{7}{*}{ var. rubrum } & & 500 & - & - & - & - \\
\hline & Hexane & 50 & - & - & - & - \\
\hline & & 500 & - & - & - & - \\
\hline & Ethyl acetate & 50 & - & - & - & - \\
\hline & & 500 & - & - & - & 7.5 \\
\hline & Water & 50 & - & - & - & - \\
\hline & & 500 & - & - & - & - \\
\hline \multirow{8}{*}{$\begin{array}{l}\text { Zingiber officinale } \\
\text { var. officinale }\end{array}$} & Methanol & 50 & - & - & - & - \\
\hline & & 500 & - & 7.2 & - & 7.3 \\
\hline & Hexane & 50 & - & - & - & - \\
\hline & & 500 & - & - & - & - \\
\hline & Ethyl acetate & 50 & - & - & - & - \\
\hline & & 500 & - & - & 7.3 & 7.8 \\
\hline & Water & 50 & - & - & - & - \\
\hline & & 500 & - & - & - & - \\
\hline Gentamycin, $10 \mu \mathrm{g} / \mathrm{disc}$ & & & 20.7 & 18.0 & 22.0 & 19.0 \\
\hline Ampicilin, $10 \mu \mathrm{g} / \mathrm{disc}$ & & & NT & 32.5 & 37.0 & 38.5 \\
\hline
\end{tabular}


The most pronounced activity with inhibition zones of more than $14.0 \mathrm{~mm}$ was shown by methanol extract (inhibition zone $19.3 \mathrm{~mm}$ against Bacillus subtilis at concentration $500 \mathrm{mg} \mathrm{mL}^{-1}$ ) and hexane fraction (inhibition zone $15.0 \mathrm{~mm}$ against Pseudomonas aeruginosa at concentration $500 \mathrm{mg} \mathrm{mL}^{-1}$ ) of Curcuma mangga. In addition, the methanol extract of Curcuma mangga had a remarked sensitivity towards Pseudomonas aeruginosa and Staphylococcus aureus, with inhibition zones 13.0 and $10.5 \mathrm{~mm}$ at concentration $500 \mathrm{mg} \mathrm{mL}^{-1}$ respectively. The hexane fraction of Curcuma mangga also showed significant antimicrobial activity against Staphylococcus aureus and Bacillus subtilis with inhibition zones 9.5 and $13.5 \mathrm{~mm}$ at concentration $500 \mathrm{mg} \mathrm{mL}^{-1}$ respectively whilst the ethyl acetate fraction showed inhibition against Pseudomonas aeruginosa, Staphylococcus aureus and Bacillus subtilis with inhibition zones 11.5, $9.0,13.7 \mathrm{~mm}$ respectively at concentration $500 \mathrm{mg}$ $\mathrm{mL}^{-1}$. When the concentration of the extracts were decreased from $500-50 \mathrm{mg} \mathrm{mL} \mathrm{m}^{-1}$, slight decrease in inhibition zones were observed. A recent phytochemical study of Curcuma mangga revealed the presence of labdane-type diterpene compounds and these compounds are similar to those that have been reported to possess strong antimicrobial activity against Gram positive, Gram negative bacteria and pathogenic fungi ${ }^{[1,10]}$. It is likely that the presence of this type of compounds may have contributed to the antimicrobial activity of Curcuma mangga.

At concentration $500 \mathrm{mg} \mathrm{mL}^{-1}$, the methanol, hexane and ethyl acetate extracts of Curcuma inodora showed inhibition against Pseudomonas aeruginosa and Staphylococcus aureus. The methanol and ethyl acetate extracts of Curcuma inodora also showed modest inhibition against Bacillus subtilis at both concentrations of 500 and $50 \mathrm{mg} \mathrm{mL}^{-1}$.

The methanol, hexane and ethyl acetate extracts of Pereskia bleo, at the concentration of $500 \mathrm{mg} \mathrm{mL}^{-1}$, exhibited modest inhibition against Pseudomonas aeruginosa at 9.8, 9.5 and $8.5 \mathrm{~mm}$, respectively. When the concentrations of these three extracts are lowered to $50 \mathrm{mg} \mathrm{mL}^{-1}$, a slight decline in the inhibition zone were shown by the methanol and ethyl acetate extracts whilst the hexane extract showed no inhibition at all (Table 1). The hexane and ethyl acetate extracts of Pereskia bleo, at the concentration of $500 \mathrm{mg} \mathrm{mL}^{-1}$, also showed modest inhibition against Bacillus subtilis at 8.2 and 7.8 $\mathrm{mm}$, respectively. However, only the ethyl acetate extract of Pereskia grandifolia showed some antimicrobial activity against $P$ seudomonas aeruginosa,
Staphylococcus aureus and Bacillus subtilis at concentration of $500 \mathrm{mg} \mathrm{mL}^{-1}$.

Antimicrobial activity of jahe gajah (Zingiber officinale var. officinale) showed no inhibition against all the bacteria used in this study except a small inhibition zone of $7.5 \mathrm{~mm}$ against Bacillus subtilis at concentration $500 \mathrm{mg} \mathrm{mL}^{-1}$. The methanol extract of jahe emprit (Zingiber officinale var. rubrum) showed inhibition against Pseudomonas aeruginosa and Bacillus subtilis whilst its ethyl acetate extract inhibited the growth of Staphylococcus aureus and Bacillus subtilis at concentration of $500 \mathrm{mg} \mathrm{mL}^{-1}$ (Table 1).

At concentration of $500 \mathrm{mg} \mathrm{mL}^{-1}$, the methanolic extract of Curcuma zedoaria exhibited antimicrobial activity against Pseudomonas aeruginosa whilst the ethyl acetate extract of Curcuma zedoaria showed antimicrobial activity against Bacillus subtilis. The hexane extract of Curcuma zedoaria, however, is observed to inhibit the growth of Pseudomonas aeruginosa, Staphylococcus aureus and Bacillus subtilis at concentration of $500 \mathrm{mg} \mathrm{mL}^{-1}$. There is a slight decrease in inhibition of Staphylococcus aureus by the hexane extract of Curcuma zedoaria concentration of $50 \mathrm{mg} \mathrm{mL}^{-1}$.

The ethyl acetate extract of Curcuma aeruginosa showed inhibition against Pseudomonas aeruginosa, Staphylococcus aureus and Bacillus subtilis at concentration of $500 \mathrm{mg} \mathrm{mL}^{-1}$ while at $50 \mathrm{mg} \mathrm{mL}^{-1}$, its ethyl acetate extract showed inhibition against Bacillus subtilis. Both hexane and methanolic extract of Curcuma aeruginosa showed antimicrobial activity against Pseudomonas aeruginosa and Staphylococcus aureus with inhibition zones of $7.5 \mathrm{~mm}$ each, at concentration of $500 \mathrm{mg} \mathrm{mL}^{-1}$. The hexane extract of Curcuma aeruginosa also showed antimicrobial activity against Pseudomonas aeruginosa with inhibition zone of $7.2 \mathrm{~mm}$ at concentration of $50 \mathrm{mg} \mathrm{mL}^{-1}$.

\section{CONCLUSION}

Curcuma mangga exhibit some degree of antibacterial activity towards Pseudomonas aeruginosa, Staphylococcus aureus and Bacillus subtilis. Thus, it shows that some of the medicinal plants used in traditional medicine are potentially effective antimicrobial agents. None of the plants tested in this study inhibited the growth of Escherichia coli. Investigation of the antimicrobial compounds in Curcuma mangga is now underway. The resulting information will contribute to a better understanding of the antimicrobial activity of the plant. 


\section{ACKNOWLEDGEMENT}

This study was supported by a research fund from the University of Malaya (Vote F F0155/2005D) and the Ministry of Science, Technology and Innovation, Malaysia (MOSTI) (E-sciencefund 12-02-03-2026). We are also grateful to Professor Dr. A. Hamid A. Hadi for use of his laboratory facilities.

\section{REFERENCES}

1. Abas, F., N.H. Lajis, K. Shaari, D.A. Israf, J. Stanslas, U.K. Yusuf, and S.M. Raof, 2005. A Labdane Diterpene Glucoside from the Rhizomes of Curcuma mangga. J. Nat. Prod., 68: 1090-1093.

http://www.ncbi.nlm.nih.gov/pubmed/16038556

2. Banerjee, A., V.K. Kaul, and S.S. Nigam, 1978. Antimicrobial efficacy of the essential oil of Curcuma zedoaria (Rosc.) Roxb. Indian Perfumer, 22: 214-217.

3. Galal M., A.K. Bashir, A.M. Salih, and S.E.I., Adam, 1991. Activity of water extracts of Albiziaanthelmintica and A. lebbek backs against exprimental Hymenolepis diminuta infection in rats. J. Ethnopharmacol., 31: 333-337.

3. Harvey, A.L., 1999. Medicines from nature: are natural products still relevant to drug discovery? Trends Pharmacol.. Sci., 20: 196-198. DOI: 10.1016/S0165-6147(99)01346-2.

4. Hoffmann J.J., N., Timmerman, R. Mclaughlin, and H. Punnapayak, 1993. Potential antimicrobial activity of plants from the South Western United States. Int. J. Pharmacolog., 31:101-115. DOI: 10.3109/13880209309082926

5. Jantan, I., 1998. Conservation of medicinal plants and their traditional knowledge. Medicinal plants: cure for the $21^{\text {st }}$ century (Biodiversity, conservation and utilization of medicinal plants), Nair, M.N.B., G. Nathan, (Eds.), In the proceedings of the seminar University Putra Malaysia, October 15-16, pp: 20-24.

6. Lai, Y.C. Eric, C.C. Chyau, J.L. Mau, C.C. Chen, Y.J., Lai, C.F. Shih, and L.L. Lin, 2004. Antimicrobial activity and cytotoxicity of the essential oil of Curcuma zedoaria. A.m. J. Chinese Med., 32:281-290. DOI: 10.1142/S0192415X0400193X

7. Lopez, P., C. Sanchez, R. Batlle, and R. Nerin, 2005. Solid- and vapor-phase antimicrobial activities of six essential oils: susceptibility of selected foodborne bacterial and fungi strains. J. Agri. Food Chem., 53: 6939-6946.
8. Phan, M.G., N.G. Van, and T.S. Phan, 2000. Antimicrobial activity of sesquiterpene constituents from Curcuma species of Vietnam. Tap Chi Hoa Hoc, 38: 91-94.

9. Pyo, D. and H.H. Oo, 2007. Supercritical fluid extraction of drug-like materials from selected Myanmar natural plants and their antimicrobial activity. J. Liquid Chromatograp. Related Technol., 30: 377-392. $\quad$ DOI: 10.1080/10826070601084837

10. Kalpoutzakis, E., N. Aligiannis, S. Mitaku, I. Chinou, C. Harvala, and A.L. Skaltsounis, 2001. New semisynthetic antimicrobial labdane-type diterpenoids derived from the resin "Ladano" of Cistus creticus. J. Biosci., 56, 49-52. http://www.znaturforsch.com/ac/v56c/56c0049.pdf

11. Ramzi, Mothana A.A. and Ulrike Lindequist, 2005. Antimicrobial activity of some medicinal plants of the island Soqotra. J. Ethnopharmacol., 96: 177-181. DOI:10.1016/j.jep.2004.09.006

12. Rao, B.G.V. and S.S. Nigam, 1970. In vitro antimicrobial efficiency of essential oils. Indian J. Med. $\quad$ Res., 58: 627-633. http://www.ncbi.nlm.nih.gov/pubmed/5536172

13. Rath, C. Chandi, S.K. Dash, and R.K. Mishra, 2002. Antibacterial efficacy of six Indian essential oils individually and in combination. J. Essential Oil-Bearing Plants, 5: 99-107.

14. Sofia, P.K., R. Prasad, V.K. Vijay, and A.K. Srivastava, 2007. Evaluation of antibacterial activity of Indian spices against common foodborne pathogens. Int. J. Food Sci. Technol., 42: 910-915.

http://www3.interscience.wiley.com/journal/11798 9175/abstract?CRETRY $=1 \&$ SRETRY $=0$

15. Srinivasan, D., Nathan, Sangeetha, T. Suresh, and Perumalsamy, P. Lakshmana, 2001. Antimicrobial activity of certain Indian medicinal plants used in folkloric medicine. J. Ethnopharmacology, 74: 217-220. DOI: 10.1016/S0378-8741(00)003457

16. Wilson B., G. Abraham V.S. Manju, M. Mathew, B. Vimala, S. Sundaresan and B. Nambisan, 2005. Antimicrobial activity of Curcuma zedoaria and Curcuma malabarica tubers. J. Ethopharmacol., 99: 147-151. DOI: 10.1016/j.jep.2005.02.004 